\title{
Blunted Response of Growth Hormone to Clonidine and Apomorphine in Endogenous Depression
}

\author{
M. ANSSEAU, R. VON FRENCKELL, J. L. CERFONTAINE, P. PAPART,
} G. FRANCK, M. TIMSIT-BERTHIER, V. GEENEN and J. J. LEGROS

\begin{abstract}
We measured the growth hormone (GH) response to clonidine (an alpha-2-adrenergic agonist) and to apomorphine (a dopaminergic agonist) in 15 major endogenous and 15 minor depressive in-patients matched for gender and age. Results showed a significantly smaller $\mathrm{GH}$ response in the major depressives to both clonidine $(P<0.01)$ and apomorphine $(P<0.001)$. No significant difference existed between the two groups with regard to changes in blood pressure and pulse rate during either test. While major depressives showed a trend toward smaller sedative side-effects than minor depressives after clonidine, they showed significantly smaller sedative and gastro-intestinal side-effects after apomorphine. No significant correlation was present either in the major depressive or in the minor depressive group between the $\mathrm{GH}$ responses following clonidine and apomorphine challenges. These results support the hypothesis of both noradrenergic and dopaminergic neurotransmitter disturbances in major depression, with individual variability with regard to those biochemical anomalies.
\end{abstract}

Neuroendocrine strategy may provide an indirect index of central neurotransmission which is particularly interesting in biological psychiatry. Indeed, the release of anterior pituitary hormones depends on hypothalamic releasing factors, the secretion of which is controlled by neurotransmitters also implicated in mental illnesses. The greatest amount of information on this can be obtained from the study of growth hormone (GH) response to specific pharmacological challenges: indeed, $\mathrm{GH}$ secretion is stimulated by dopamine, noradrenaline through alpha receptors, and possibly serotonin, while it is inhibited by noradrenaline through beta receptors and by gamma-aminobutyric acid (GABA) (Checkley, 1980).

The current main pathophysiological theory of endogenous depression hypothesises a decreased activity in central neurotransmitter systems: noradrenergic, serotonergic, and possibly dopaminergic (Willner, 1985). These disturbances could result from a diminished neurotransmitter release or, as suggested more recently, from disturbances in the 'sensitivity' of specific receptors. Possible central catecholaminergic disturbances in depressive disorders have been assessed by the study of the $\mathrm{GH}$ response to various pharmacological challenges such as amphetamine, clonidine, desipramine, L-dopa, apomorphine, and carbidopa (Checkley, 1980).

With regard to noradrenergic receptors, most studies, although using poorly specific pharmacological challenges (i.e. amphetamine or desipramine), converge to suggest a smaller $\mathbf{G H}$ response among major depressive patients (Siever \& Uhde, 1984). In comparison with those pharmacological agents, clonidine exhibits a more specific alpha-2-adrenergic agonistic activity and stimulates $\mathrm{GH}$ secretion through postsynaptic alpha-2-adrenergic receptors in the hypothalamus (Lal \& Martin, 1980; Siever et al, 1982). This clonidine-induced $\mathrm{GH}$ response appears to be blunted among major depressive patients (Matussek et al, 1980; Checkley et al, 1981, 1984; Siever et al, 1982; Charney et al, 1982; Siever \& Uhde, 1984; Boyer et al, 1986), supporting an alpha-2-adrenergic receptor disturbance in major depressive disorders.

Various lines of evidence also suggest a role for dopamine in the pathophysiology of depression (Willner, 1985); but the studies of $\mathrm{GH}$ response to dopaminergic agonists such as L-dopa or apomorphine have failed to show any differences for major depressive patients (Sachar et al, 1975; Casper \& Davis, 1977; Maany et al, 1979; Linkowski et al, 1983; Corn et al, 1984a; Jimerson et al, 1984; Meltzer et al, 1984). However, it should be noted that most studies have used L-dopa, which has a low priority potency or specificity. Moreover, most results should be interpreted with caution because the samples of depressive patients and control subjects differed with regard to age, gender, and endocrine status in women, all factors which modify the reactivity to dopaminergic agonists (Ettigi et al, 1975). In comparison with L-dopa, apomorphine appears to 
be a more specific and more potent dopaminergic agonist and induces $\mathrm{GH}$ release in a more reproducible way (Rotrosen et al, 1976, 1979; La Rossa et al, 1977; Lal \& Martin, 1980; Costain et al, 1982).

In this context, the purpose of our study was to compare the $\mathrm{GH}$ response after clonidine and apomorphine challenges in two samples of major depressive and minor depressive patients matched for gender and age. We wanted to verify if major depression was associated with disturbances in alpha-2-adrenergic or dopaminergic receptors and to what extent these two different abnormalities were correlated.

\section{Mothod}

\section{Subjects}

Fifteen in-patients consecutively admitted to the Biological Psychiatry and Psychopharmacology Unit of the University Hospital of Liège, Belgium, were included in the study. They met Research Diagnostic Criteria for major depressive disorder, endogenous subtype. Moreover, they had a score of at least 6 on the Newcastle index for endogenous depression and of at least $\mathbf{2 0}$ on the Hamilton depression scale at the end of a drug-free period of at least two weeks. All patients were unipolar and none of them exhibited psychotic features. This sample comprised seven male and eight female patients, aged 26-61 years (mean age $=$ 45.2 \pm 11.3 ). Their individual characteristics are presented in Table $I$.

These patients were matched for gender, age (within three years) and, in the case of women, menopausal status with 15 in-patients meeting Research Diagnostic Criteria for minor depression, having a score less than 6 on the Newcastle index and less than 20 on the Hamilton depression scale (Table I). Weight ranges were 62-81 kg for major depressives (mean weight $=69.5 \mathrm{~kg} \pm 7.0$ ) and $61-76 \mathrm{~kg}$ for minor depressives (mean weight $=69.8 \mathrm{~kg} \pm 7.4$ ), without significant differences between the two groups $(t=0.1$, d.f. $=28$, NS).

Diagnostic procedures were performed independently by two research psychiatrists blind to neuroendocrine test results. All patients were free of medical illness as evidenced by history, medical examination, ECG, chest $X$-ray, EEG, and routine laboratory tests. They had also been free of drugs, including benzodiazepines, for at least two weeks at the time of the study. The neuroendocrine tests were performed between the third and the twelfth day of the menstrual cycle in pre-menopausal women (four in each group: patients 1, 3, 5, 7 and 16, 18, 20,22 ). Patients with a basal systolic blood pressure less than $100 \mathrm{mmHg}$ were excluded from the study. Moreover, in order to be included, patients had to present basal $(t 0)$ GH level less than $5 \mathrm{ng} / \mathrm{ml}$ before both pharmacological challenges (Ansseau et al, 1984). All patients were fully informed of the purpose of the study and gave written consent.

\section{Neuroendocrine test procedures}

Clonidine and apomorphine challenge tests were performed in this order according to the same procedure with an interval of at least two days between the tests.

At 07:00, after an overnight fast, an indwelling catheter was inserted in a forearm vein. Blood samples of $10 \mathrm{ml}$ were collected every 20 minutes from $\mathbf{4 0}$ minutes before to 120 minutes after injection, at 08:00, of either clonidine (0.15 mg diluted in saline to obtain $20 \mathrm{ml}$ intravenously in ten minutes), or apomorphine ( $0.5 \mathrm{mg}$ diluted in saline to obtain $0.5 \mathrm{ml}$ subcutaneously).

After each blood sampling, blood pressure, pulse rate and sedative and gastro-intestinal side-effects were recorded. In addition, at the end of the procedure, sedative and gastrointestinal side-effects were globally rated according to a sixpoint scale by a research nurse blind to diagnosis. The level of alertness was rated according to the following scores: $0=$ no change; $1=$ very slight drowsiness; 2 = slight drowsiness; 3 =drowsiness; $4=$ important drowsiness; $5=$ sleep. Gastro-intestinal reactions were rated according to the following scores: $\mathbf{0}=$ no reaction; $\mathbf{1}=$ slight and transitory nausea; 2 =nausea; $3=$ strong nausea without vomiting; $4=$ vomiting; $5=$ severe vomiting .

\section{GH assay}

GH was measured with a double antibody radioimmunoassay (Franchimont, 1968), with intra- and inter-assay coefficients of variation of respectively $13.3 \pm 4.7 \%$ and $14.8 \pm 9.6 \%$ and a detection limit of $0.2 \mathrm{ng} / \mathrm{ml}$.

\section{Data analysis}

GH responses following clonidine and apomorphine were assessed by two different methods: by GH peak values following injection and by the areas under the curve situated between injection $(t 0)$ and the last blood sampling $(t 120 \mathrm{~min})$. Both analyses were performed using absolute $\mathrm{GH}$ values as well as differences related to basal $(t 0)$ levels (relative values). Since the correlations between absolute and relative values (assessed by Pearson's correlation coefficient) were very high $(r>0.98)$, only the absolute values are reported here.

Changes over time in blood pressure and pulse rate were assessed by variance analysis (ANOVA) with repeated measures. GH responses and sedative and gastro-intestinal side-effects in major and minor depressives were compared using paired t-tests. Since some variances were high compared with mean values, the comparison was also performed by means of the Wilcoxon non-parametric test. The relationship between individual GH responses after clonidine and apomorphine as well as the relationships between $\mathrm{GH}$ response and sedative and gastro-intestinal sideeffects were assessed by Pearson's correlation coefficient.

\section{Results}

\section{Clonidine test}

The changes over time in mean GH level following clonidine among the 15 major and the 15 minor depressive patients 
TABLE I

Characteristics of the sample and individual responses to clonidine and apomorphine challenges

\begin{tabular}{|c|c|c|c|c|c|c|c|c|}
\hline \multirow[t]{2}{*}{ Patient } & \multirow[t]{2}{*}{$\operatorname{Sex}$} & \multirow[t]{2}{*}{ Age } & \multirow[t]{2}{*}{ Diagnosis' } & \multicolumn{2}{|c|}{ Clonidine test } & \multicolumn{3}{|c|}{ Apomorphine test } \\
\hline & & & & $\begin{array}{c}G H \text { peak: } \\
\text { ng/ml }\end{array}$ & $\begin{array}{c}\text { Sedation } \\
\text { rating }\end{array}$ & $\begin{array}{c}\text { GH peak: } \\
\text { ng/ml }\end{array}$ & $\begin{array}{c}\text { Gastro- } \\
\text { intestinal } \\
\text { effects rating }\end{array}$ & $\begin{array}{c}\text { Sedation } \\
\text { rating }\end{array}$ \\
\hline 1 & $\mathbf{F}$ & 26 & Major, end., UP & 1.2 & 1 & 2.9 & $\mathbf{0}$ & 2 \\
\hline 2 & $\mathbf{M}$ & 30 & Major, end., UP & 27.7 & 2 & 5.7 & 0 & 0 \\
\hline 3 & $\mathbf{F}$ & 30 & Major, end., UP & 6.8 & 2 & 5.2 & 4 & 3 \\
\hline 4 & $\mathbf{M}$ & 38 & Major, end., UP & 1.7 & $\mathbf{0}$ & 2.2 & 1 & $\mathbf{0}$ \\
\hline 5 & $\mathbf{F}$ & 38 & Major, end., UP & 1.8 & 3 & 12.9 & 0 & 3 \\
\hline 6 & $\mathbf{M}$ & 39 & Major, end., UP & 5.5 & 5 & 12.5 & 0 & 0 \\
\hline 7 & $\mathbf{F}$ & 41 & Major, end., UP & 4.6 & 1 & 5.0 & 1 & 0 \\
\hline 8 & $\mathbf{M}$ & 50 & Major, end., UP & 1.0 & 0 & 5.7 & 4 & 0 \\
\hline 9 & $\mathbf{F}$ & 51 & Major, end., UP & 1.4 & 2 & 7.4 & $\mathbf{0}$ & 0 \\
\hline 10 & $\mathbf{M}$ & 51 & Major, end., UP & 1.6 & 1 & 1.8 & 1 & 0 \\
\hline 11 & $\mathbf{F}$ & 53 & Major, end., UP & 1.1 & 1 & 1.6 & 0 & 0 \\
\hline 12 & $\mathbf{M}$ & 55 & Major, end., UP & 1.0 & 2 & 9.7 & 0 & 0 \\
\hline 13 & $\mathbf{F}$ & 56 & Major, end., UP & 0.5 & 4 & 1.3 & 0 & 0 \\
\hline 14 & $\mathbf{M}$ & 59 & Major, end., UP & 2.3 & 0 & 3.6 & 2 & 0 \\
\hline 15 & $\mathbf{F}$ & 61 & Major, end., UP & 1.6 & $\mathbf{0}$ & 2.7 & 2 & $\mathbf{0}$ \\
\hline 16 & $\mathbf{F}$ & 26 & Minor & 7.6 & 5 & 32.4 & 3 & 4 \\
\hline 17 & $\mathbf{M}$ & 28 & Minor & 3.8 & 2 & 23.9 & 3 & 5 \\
\hline 18 & $\mathbf{F}$ & 28 & Minor & 14.1 & 5 & 27.9 & 4 & 2 \\
\hline 19 & $\mathbf{M}$ & 36 & Minor & 13.4 & 3 & 21.4 & 4 & 3 \\
\hline 20 & $\mathbf{F}$ & 36 & Minor & 12.8 & 4 & 5.9 & 2 & 2 \\
\hline 21 & $\mathbf{M}$ & 42 & Minor & 14.9 & 3 & 14.5 & 2 & 3 \\
\hline 22 & $\mathbf{F}$ & 41 & Minor & 11.4 & $\mathbf{0}$ & 25.0 & 3 & 2 \\
\hline 23 & $\mathbf{M}$ & 47 & Minor & 4.7 & 5 & 11.1 & 3 & 0 \\
\hline 24 & $\mathbf{F}$ & 51 & Minor & 1.2 & 2 & 18.1 & $\mathbf{0}$ & 0 \\
\hline 25 & $\mathbf{M}$ & 52 & Minor & 24.0 & 3 & 7.3 & 5 & 2 \\
\hline 26 & $\mathbf{F}$ & 52 & Minor & 17.7 & 2 & 0.8 & 1 & 0 \\
\hline 27 & $\mathbf{M}$ & 54 & Minor & 3.2 & 4 & 20.9 & 3 & 1 \\
\hline 28 & $\mathbf{F}$ & 54 & Minor & 15.4 & 0 & 49.5 & 3 & 0 \\
\hline 29 & $\mathbf{M}$ & 60 & Minor & 26.4 & 0 & 35.1 & 3 & 3 \\
\hline 30 & $\mathbf{F}$ & 63 & Minor & 5.6 & 3 & 12.5 & 0 & 4 \\
\hline
\end{tabular}

1. Major = major depression; Minor = minor depression; end. = endogenous; UP = unipolar.

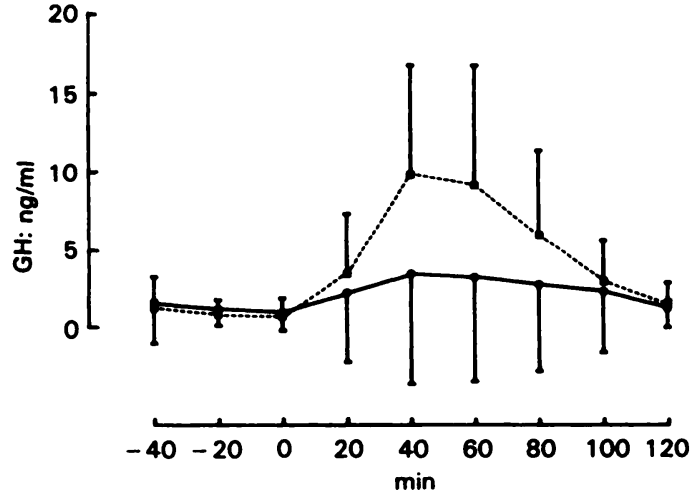

Fic. 1 Changes over time in mean GH level ( \pm s.d.) following clonidine (0.15 mg i.v.) in 15 major $(\longrightarrow)$ and 15 minor ( $(-\cdots)$ depressive patients. matched for gender and age are presented in Fig. 1. Individual endocrine and clinical data are shown in Table $I$. Major depressives exhibited a significantly lower $\mathbf{G H}$ response than minor depressives: for peak values, $4.0 \pm 6.8 \mathrm{ng} / \mathrm{ml}$ vs $11.7 \pm 7.5 \mathrm{ng} / \mathrm{ml}, z=-3.3, P<0.01$, and for the areas under the response curve, $301 \pm 538 \mathrm{ng} \mathrm{min} / \mathrm{ml}$ vs $653 \pm 424 \mathrm{ng} \mathrm{min} / \mathrm{ml}, z=2.9, P<0.01$.

Blood pressure exhibited a significant decrease following clonidine for the whole sample $(F(6,168)=16.4$, $P<0.00001$ for systolic blood pressure, and $F(6,168)=5.5$, $P<0.0005$ for diastolic blood pressure), but without significant difference between major and minor depressives $(F(1,28)=0.5$, NS for systolic blood pressure, and $F(1$, 28) $=0.1$, NS for diastolic blood pressure). Pulse rate did not show any significant change.

Ratings of sedative effects exhibited a trend toward lesser severity among major depressive than among minor depressive patients (1.6 vs 2.7, $U=-1.8, P=0.07$ ). No significant relationship was present between individual 


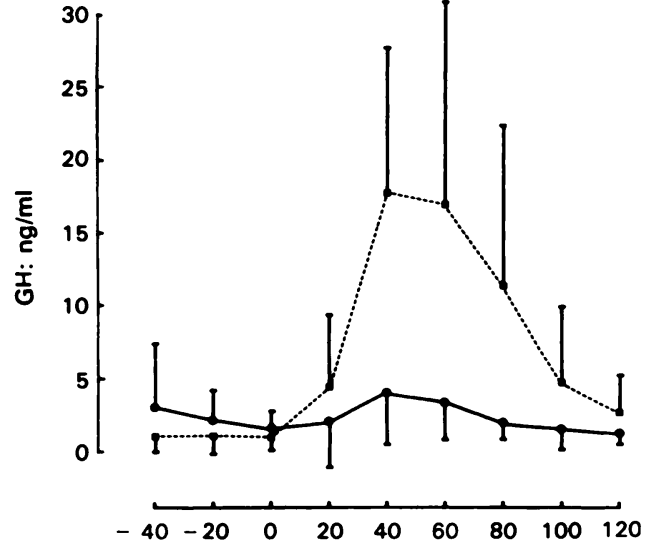

FIc. 2 Changes over time in mean GH level ( \pm s.d.) following apomorphine $(0.5 \mathrm{mg}$ s.c.) in 15 major (๑) and 15 minor (घ-.-) depressive patients.

GH responses and ratings of sedative reactions $(r=-0.17$, d.f. $=28$, NS).

\section{Apomorphine test}

The changes over time in mean GH level following apomorphine among the 15 major and the 15 minor depressive patients are presented in Fig. 2. Individua endocrine and clinical data are shown in Table I. Major depressive patients exhibited a significantly lower $\mathrm{GH}$ response than minor depressives: $5.3 \pm 3.8 \mathrm{ng} / \mathrm{ml}$ vs $20.4 \pm 12.7 \mathrm{ng} / \mathrm{ml}, z=3.5, P<0.001$ for peak values, and $281 \pm 159 \mathrm{ng} \mathrm{min} / \mathrm{ml}$ vs $1134 \pm 745 \mathrm{ng} \mathrm{min} / \mathrm{ml}, z=3.7$, $P<0.001$ for the areas under the response curve.

Blood pressure exhibited a significant decrease for the whole sample $(F(6,168)=3.2, P<0.05$ for systolic blood pressure, and $F(6,168)=2.8, P<0.05$ for diastolic blood pressure), without significant difference between the two groups $(F(1,28)=0.5$, NS for systolic blood pressure, and $F(1,28)=3.0$, NS for diastolic blood pressure). Pulse rate did not exhibit any significant changes over time.

Ratings of both gastro-intestinal and sedative sideeffects were significantly lower among major as compared with minor depressives (respectively 1.0 vs 2.6, $U=2.7$, $P<0.01$, and 0.5 vs $2.1, U=2.7, P<0.01$ ). While the relationships between gastro-intestinal side-effects and $\mathbf{G H}$ response and between sedative side-effects and $\mathrm{GH}$ response were not significant in either of the two isolated groups (for gastro-intestinal reactions, $r=-0.20$ among major depressives and $r=0.29$ among minor depressives; for sedative reactions, $r=0.29$ among major depressives and $r=0.11$ among minor depressives), these relationships became significant when the whole sample was included in the analysis $(r=0.42$, d.f. $=28, P<0.05$ for gastro-intestinal reactions, and $r=0.40$, d.f. $=28, P<0.05$ for sedative reactions).

\section{Relationship between GH responses} following clonidine and apomorphine

No significant correlation was present between individual GH peaks following clonidine and apomorphine among major depressive or minor depressive patients $(r=0.11$ for major depressives and $r=0.06$ for minor depressives). However, if both subgroups were pooled together, a slightly significant relationship existed $(r=0.36$, d.f. $=28, P<0.05)$.

\section{Discussion}

Concerning the clonidine test, the results of our study show a smaller $\mathrm{GH}$ response in major depressive as compared with minor depressive patients. These results are in agreement with previous studies comparing the $\mathrm{GH}$ response to clonidine in major depressive patients and normal controls (Matussek et al, 1980; Checkley et al, 1981; Charney et al, 1982; Siever et al, 1982; Siever \& Uhde, 1984; Boyer et al, 1986) or reactive depressives (Checkley et al, 1984). The only negative report used oral clonidine in a small sample of seven endogenous and seven nonendogenous depressive patients (Dolan \& Calloway, 1986); it is unclear if $0.15 \mathrm{mg}$ of oral clonidine is able to consistently stimulate $\mathrm{GH}$ release over a two-hour period. These findings suggest a hyposensitivity of postsynaptic alpha-2-adrenergic hypothalamic receptors in major depression, since $\mathrm{GH}$ response to clonidine seems to depend on the stimulation of those receptors (review in Siever et al, 1982).

The lack of difference between major and minor depressives with regard to hypotensive response following clonidine is in agreement with three previous studies showing similar changes in blood pressure among major depressives and normal controls (Checkley et al, 1981; Siever \& Uhde, 1984; Siever et al, 1984). The lack of global modification of pulse rate following clonidine also confirms the study of Checkley et al (1981). However, Siever \& Uhde (1984) and Siever et al (1984) found a smaller decrease in pulse rate in major depressives than in normal subjects. It should be noted, however, that besides the classical mechanism explaining clonidineinduced hypotension by a stimulation of alpha-2adrenergic receptors in the brain areas responsible for cardiovascular control, various lines of evidence suggest a role for $\mathrm{H}_{2}$ histaminic receptors (review in Pettinger, 1980).

The trend toward smaller sedative side-effects in the major depressive group is in agreement with the hypothesis of a central noradrenergic hyposensitivity. However, Checkley et al (1981) did not find any significant difference between major depressives and normal subjects in the changes over time of sedative effect assessed by visual analogue scales completed 
by the subject every 15 minutes. It should be noted that the mechanism of the sedative effect induced by clonidine is most probably of noradrenergic origin; a possible interpretation of these sedative effects in muscarinic receptor or $\mathrm{H}_{2}$ histaminic receptor stimulation did not find experimental support (Spyraki \& Fibiger, 1982).

Following apomorphine, major depressive patients also exhibit a smaller $\mathrm{GH}$ response as compared with minor depressive patients. These results, which suggest a hyposensitivity of dopaminergic hypothalamic receptors controlling $\mathrm{GH}$ release in major depression, disagree with previous reports. Most studies have used L-dopa without finding disturbances in GH response in unipolar depressive patients (Sachar et al, 1975; Maany et al, 1979; Linkowski et al, 1983). It should be noted, however, that L-dopa has a low dose of specificity for the dopamine receptors and that it is not demonstrated that L-dopa-induced $\mathrm{GH}$ response depends on dopaminergic receptor stimulation. Indeed, this release is inhibited not only by chlorpromazine, a dopaminergic receptor antagonist, but also by phentolamine, an alpha-adrenergic antagonist, and by cyproheptadine, a serotonergic antagonist; moreover, L-dopa-induced GH response is increased by propanolol, a beta-blocker (review in Lal \& Martin, 1980). Compared to L-dopa, apomorphine seems to induce $\mathrm{GH}$ secretion by more specifically dopaminergic mechanisms. Indeed, apomorphine-induced GH release is only inhibited by pharmacological agents exhibiting dopaminergic antagonist properties (neuroleptics), such as chlorpromazine, haloperidol, pimozide, sulpiride, or clozapine (review in Lal \& Martin, 1980). Moreover, apomorphine appears a much more potent and reproducible stimulus of $\mathrm{GH}$ secretion than L-dopa. In three studies where GH responses to apomorphine ( $0.75 \mathrm{mg}$ subcutaneously) and L-dopa (500 $\mathrm{mg}$ orally) were compared in the same normal subjects, apomorphine induced a GH response in all 26 subjects, while L-dopa was only effective in 16 subjects (62\%) (Lal et al, 1975; Rotrosen et al, 1976; La Rossa et al, 1977). Moreover, the $\mathrm{GH}$ response is highly reproducible in the same subjects if the test is repeated (Rotrosen et al, 1979; Costain et al, 1982).

Few studies have used apomorphine-induced $\mathrm{GH}$ stimulation in depressive patients, and none has shown differences with normal subjects (Casper \& Davis, 1977; Maany et al, 1979; Jimerson et al, 1984; Meltzer et al, 1984). A possible explanation for these negative results is the use in these studies of an apomorphine dose of $0.75 \mathrm{mg}$ rather than $0.50 \mathrm{mg}$ as in our study. A $0.75 \mathrm{mg}$ dose could be potent enough to induce a complete $\mathrm{GH}$ response even in case of relative hyposensitivity of hypothalamic receptors.

Recently, Corn et al (1984a) performed clonidine and apomorphine challenges in the same eight patients with endogenous depression and found significantly lower $\mathrm{GH}$ response following clonidine than following apomorphine. However, no control group was included in this study and the selection of the doses of clonidine $(1.3 \mu \mathrm{g} / \mathrm{kg})$ and apomorphine $(0.005 \mathrm{mg} / \mathrm{kg})$ was based on small studies in different groups of normal subjects (Costain et al, 1982; Corn et al, 1984b) which showed striking interpatient variability in the $\mathrm{GH}$ response.

The relative hyposensitivity of dopamine receptors in major depressives as compared with minor depressives is confirmed by the major depressives' lower rate of sedative and gastro-intestinal sideeffects induced by apomorphine. These effects have never before been specifically assessed in depressive patients.

We can interpret the blunted $\mathrm{GH}$ response to clonidine and apomorphine as indirect evidence for both noradrenergic and dopaminergic abnormalities in endogenous depression. However, an alternative and even more simple explanation could be that endogenous depressive patients exhibit disturbances in GH production or secretion itself (review in Matussek, 1988). Supporting this hypothesis, a recent study demonstrated lower spontaneous $\mathrm{GH}$ secretion over a four-hour period in endogenous depressive patients as compared with neurotic depressive patients and normal subjects (Boyer et al, 1986). However, a previous report of 24-hour profile of plasma GH concentrations showed diurnal hypersecretion of $\mathbf{G H}$ in major depressive patients as compared with normal subjects (Mendlewicz et al, 1985). In our study, no difference in GH secretion between major and minor depressive patients was present over the $\mathbf{4 0}$ minutes preceding clonidine or apomorphine injection.

Whether the blunted $\mathrm{GH}$ response to the various tests in endogenous depression is due to a $\mathbf{G H}$ releasing factor (GRF) deficit is uncertain. Cerebrospinal fluid GRF levels in bipolar patients were found to be the same as in controls (Berrettini et al, 1987), but several recent preliminary studies testing the $\mathrm{GH}$ response to GRF yielded controversial results. Eriksson (1985) and Krishnan et al (1986) found a significantly higher $\mathrm{GH}$ peak response to GRF in major depressive patients as compared with controls, while Risch et al (1986) reported a lower $G H$ response 15 minutes after GRF injection in five major depressive patients as compared with eleven age- and gender-matched normal subjects. 


\section{Acknowledgements}

Our gratitude is due to Mrs Ch. Gayetot for her secretarial assistance. This work was supported in part by a grant from the Fondation Médicale Reine Elisabeth (Belgium).

\section{References}

Ansseau, M., Scheyvaerts, M., Doumont, A., Poirrier, R., LEGros, J. J. \& Franck, G. (1984) Concurrent use of REM latency, dexamethasone suppression, clonidine, and apomorphine tests as biological markers of endogenous depression: a pilot study. Psychiatry Research, 12, 261-272.

Berrettini, W. H., Nurnberger, J. I. Jr \& Simmons-Alling, S. (1987) Growth hormone releasing factor in human cerebrospinal fluid. Psychiatry Research, 22, 141-147.

Boyer, P., Davila, M., Schaub, C. \& Nassiet, J. (1986) Growth hormone response to clonidine stimulation in depressive states Part I. Psychiatrie et Psychobiologie, 1, 189-195.

CASPER, R. \& DAvis, J. (1977) Neuroendocrine and amine studies in affective illness. Psychoneuroendocrinology, 2, 105-113.

Charney, D. S., Heninger, G. R., Sterngerg, D. E., Hafstad, K. M., GidDings, S. \& LANDIS, D. H. (1982) Adrenergic receptor sensitivity in depression: effects of clonidine in depressed patients and healthy subjects. Archives of General Psychiatry, 39, 290-294.

Checkley, S. A. (1980) Neuroendocrine tests of monoamine function in man: a review of basic theory and its application to the study of depressive illness. Psychological Medicine, 10 35-53.

-, SLADE, A. P. \& Shur, E. (1981) Growth hormone and other responses to clonidine in patients with endogenous depression. British Journal of Psychiatry, 138, 51-55.

-, Glass, I. B., Thompson, C., Corn, T. \& Robinson, P. (1984) The GH response to clonidine in endogenous as compared with reactive depression. Psychological Medicine, 14, 773-777.

Corn, T. H., Hale, A. S., Thompson, C., Bridges, P. K. \& CheCKLey, S. A. (1984a) A comparison of the growth hormone responses to clonidine and apomorphine in the same patients with endogenous depression. British Journal of Psychiatry, 144, 636-639.

-, Thompson, C. \& Checkley, S. A. (1984b) Effects of desipramine treatment upon central adrenoreceptor function in normal subjects. British Journal of Psychiatry, 145, 139-145.

Costain, D. W., Cowen, P. J., Gelder, M. G. \& Grahame-Smith, D. G. (1982) Electroconvulsive therapy and the brain: evidence for increased dopamine-mediated responses. The Lancet, $i$, 400-404.

Dolan, R. J. \& Calloway, S. P. (1986) The human growth hormone response to clonidine: relationship to clinical and neuroendocrine profile in depression. American Journal of Psychiatry, 143, 772-774.

Erixsson, E. (1985) Experimental Psycho-neuro-endocrinology: Brain Alpha $z_{-}$-adrenoreceptor Function and Growth Hormone Release. Göteborg: Medi Press.

Ettigi, P., Lal, S., Martin, J. B. \& Friesen, H. G. (1975) Effects of sex, oral contraceptives, and glucose loading on apomorphineinduced growth hormone secretion. Journal of Clinical Endocrinology and Metabolism, 40, 1094-1098.

Franchimont, P. (1968) Le dosage radio-immunologique de l'hormone de croissance humaine. Cahiers Médicaux Lyonnais, 44, 887-898.

Jimerson, D. C., Cutler, N. R., Post, R. M. Rey, A., Gold, P. W., Brown, G. M. \& BUNNEY Jr, W. E. (1984) Neuroendocrine responses to apomorphine in depressed patients and healthy control subjects. Psychiatry Research, 13, 1-12.

Krishnan, K. R. R., Manepalli, A., Rayasam, M. L., Melville, G., Daughtry, G., Rivier, J., Vale, W., Thorner, M. D. \&
Nemeroff, C. B. (1986) Somatotroph response to GHRF in depression. 15th CINP Congress, San Juan, Puerto Rico.

Lal, S., Martin, J. B., de la Vega, C. E. \& Friesen, H. G. (1975) Comparison of the effect of apomorphine and L-DOPA on serum growth hormone levels in normal men. Clinical Endocrinology, 4, 277-285.

— \& (1980) Neuroanatomy and neuropharmacological regulation of neuroendocrine function. In Handbook of Biological Psychiatry-Part III. Brain Mechanisms and Abnormal Behavior - Genetics and Neuroendocrinology (eds H. M. Van Praag, M. H. Lader, O. J. Rafaelsen \& E. J. Sachar). New York: Marcel Dekker.

Linkowski, P., Brauman, H. \& Mendlewicz, J. (1983) Prolactin and growth hormone response to levodopa in affective illness. Neuropsychobiology, 9, 108-112.

maany, I., Mendels, J., Frazer, A. \& Brunswick, D. (1979) A study of growth hormone release in depression. Neuropsychobiology, 5, 282-289.

MATUSSEK, N. (1988) Catecholamines and mood: neuroendocrine aspects. In Current Topics in Neuroendocrinology - Vol. 8. Neuroendocrinology and Mood (eds K. Fuxe, D. Ganten \& D. Pfaff). Berlin: Springer.

- ACKenHell, M., Hippius, H., MOLler, F. T., SChrOder, F., SchULTES, H. \& WASILEWSKI, B. (1980) Effect of clonidine on growth hormone release in psychiatric patients and controls. Psychiatry Research, 2, 25-36.

Meltzer, H. Y., Kolakowska, T., Fang, V. S., Fogg, L., Robertson, A., Lewine, R., Strahilevitz, M. \& Busch, D. (1984) Growth hormone and prolactin response to apomorphine in schizophrenia and the major affective disorders. Archives of General Psychiatry, 41, 512-519.

Mendelwicz, J., Linkowski, P., Kerkhofs, M., Desmedt, D., Goldstein, J., Copinschi, G. \& Van Cauter, E. (1985) Diurnal hypersecretion of growth hormone in depression. Journal of Clinical Endocrinology and Metabolism, 60, 505-512.

Pettinger, W. A. (1980) Pharmacology of clonidine. Journal of Cardiovascular Pharmacology, 2 (Suppl. 1), S21-S28.

Risch, S., JANOWSKY, D., JUDD, L., GILLIN, J. \& EhlERS, C. (1986) Attenuated growth hormone response to human growth hormone releasing factor in depressed subjects vs. matched controls. 15th CINP Congress, San Juan, Puerto Rico.

LA Rossa, J. T., Agrin, R. \& Melby, J. C. (1977) Apomorphinestimulated growth hormone release. American Journal of Medicine, 63, 909-913.

Rotrosen, J., Angrist, B. M., Gershon, S., Sachar, E. J. \& HaLPERN, F. S. (1976) Dopamine receptor alteration in schizophrenia: neuroendocrine evidence. Psy, hopharmacology, 51, $1-7$.

- - - - Paquin, J., Branchey, L., Oleshansky, M., HALPERN, F. \& SACHAR, E. J. (1979) Neuroendocrine effects of apomorphine: characterization of response patterns and application to schizophrenia research. British Journal of Psychiatry, 135, 444-456.

Sachar, E. J., Altman, N., Gruen, P. H., Glassman, A., HALPERN, F. S. \& SASSIN, J. (1975) Human growth hormone response to levodopa: relation to menopause, depression and plasma dopa concentration. Archives of General Psychiatry, 32, 502-503.

Siever, L. J., Uhde, T. W., Silberman, E. K., Jimerson, D. C., Alol, J. A., Post, R. M. \& MURPHY, D. L. (1982) Growth hormone response to clonidine as a probe of noradrenergic receptor responsiveness in affective disorder patients and controls. Psychiatry Research, 6, 171-183.

SIEVER, L. J. \& UHDE, T. W. (1984) New studies and perspectives on the noradrenergic receptor system in depression: effects of the alpha -adrenergic agonist clonidine. Biological Psychiatry, 19, 131-156. 
—, - - Jimerson, D. C., Lake, C. R., Silberman, E. R., Post, R. M. \& MURPHY, D. L. (1984) Differential inhibitory noradrenergic responses to clonidine in 25 depressed patients and 25 normal control subjects. American Journal of Psychiatry, 141, 733-741.

Spyraki, C. \& Fibiger, H. C. (1982) Clonidine-induced sedation in rats: evidence for mediation by postsynaptic alpha2adrenoreceptors. Journal of Neural Transmission, 54, 153-163.

WILLNER, P. (1985) Depression: a Psychobiological Synthesis. New York: Wiley.

*M. Ansseau, MD, PhD, Co-ordinator, Biological Psychiatry and Psychopharmacology Unit; R. von Frenckell, PhD, Chief Statistician; J. L. Cerfontaine, MD; P. Papart, MD; Biological Psychiatry and Psychopharmacology Unit; G. Franck, MD, PhD, Professor of Neuropsychiatry; M. Timsit-Berthier, MD, PhD, Department of Clinical Neurophysiology and Psychopathology; V. Geenen, MD, PhD; J. J. Legros, MD, PhD; Psychoneuroendocrinology Unit

*Correspondence: Centre Hospitalier Universitaire (B 35), B-4000 Liège Sart Tilman, Belgium 